\title{
ANALISA PEMBELAJARAN PKN YANG BERWAWASAN GLOBAL MELALUI INTEGRASI E-LEARNING DENGAN KARAKTER "CKKIT" (CERDAS,KRITIS,KREATIF,INOVATIF, DAN TANGGUNG JAWAB)
}

\author{
Sri Anggraini Kusuma Dewi ${ }^{1}$ \\ kusumadewi2309@gmail.com
}

\begin{abstract}
Abstrak: Dilhat dari segi proses belajar maupun dari segi media pembelajaran, proses pembelajaran pada jaman sekarang sangatlah jauh berbeda dari jaman dahulu. Dan karena majunya teknologi di jaman sekarang tentunya banyak mempengaruhi peminat dalam proses belajar. Kemajuan Teknologi yang saat ini mulai berkembang dan telah diterapkan dalam proses belajar mengajar adalah E-Learning. Namun untuk saat ini proses pemerataan dan peningkatan kualitas pendidikan dengan menggunakan program ini masih belum menunjukan angka yang memuaskan. Pembelajaran yang di dapatkan dari program ini adalah adanya rasa keingintahuan yang bisa dibilang sangat tinggi dibandingkan dengan proses belajar mengajar kuno. Karena di dalam nya peserta akan bisa langsung berinteraksi dengan pembelajar secara timbal balik. Tujuan pembelajaran adalah untuk mendapatkan pengetahuan dengan cara yang berbeda dari cara pembelajaran kuno serta merangsang keingintahuan intelektual dan memotivasi peserta untuk mencari pengetahuan berwawasan global. E-Learning akan memberikan wawasan secara global kepada para peserta didik yang berhubungan dengan segala jenis macam pengetahuan. Dan pendidikan kewarganegaraan perlu dikembangkan dengan cara pendidikan global sehingga peserta didik akan jauh lebih memahami kehidupan bermasyaraka, dan perlunya pembelajaran di sekolah dengan E-Learning Knowledge Management, untuk membantu pendidikan karakter sejak dini.
\end{abstract}

Kata Kunci: Pembelajaran, Wawasan Global, Integrasi E-learning, Knowledge Management, Karakter

\section{PENDAHULUAN}

Menurut Kamus Besar Bahasa Indonesia (KBBI) —Pendidikan yaitu sebuah proses pembelajaran bagi setiap individu untuk mencapai pengetahuan dan pemahaman yang lebih tinggi mengenai obyek tertentu dan spesifik, dan biasanya dilakukan dengan memakan waktu(一sumber : spengetahuan.coml). Pengetahuan yang diperoleh secara formal tersebut berakibat pada setiap individu yaitu memiliki pola pikir, perilaku dan akhlak yang sesuai dengan pendidikan yang diperolehnyall. Berdasarkan definisi tersebut pendidikan pada hakikaktnya tidak lah mengenal batasan usia, karena mencari pengetahuan lebih dari sebelumnya dapat dilakukan oleh siapapun tanpa memandang batasan apapun dan hanya berdasarkan dari rasa keingintahuan individu tersebut.

Dan didasarkan dari pengetahuan dan definisi tersebut maka muncullah $E$ Learning. E-Learning adalah sistem pendidikan atau proses pembelajaran yang menggunakan media aplikasi elektronik untuk membantu menunjang proses belajar mengajar dengan bantuan jaringan internet dan media pengaplikasian internet seperti komputer maupun handphone. 
Sejarah dari E-learning sendiri, pertama kali diperkenalkan oleh universitas Ilionis di Urbana Champaign dengan menggunakan sistem instruksi berbasis komputer. Membantu para peserta didik untuk meningkatkan rasa kemandirian untuk belajar dan meningkatkan rasa kreativitas peserta didik, merupakan fungsi utama dari adanya sistem pendidikan ELearning ini. Dan dari segi mencakup wilayah dengan pendidikan secara merata di setiap bagian wilayah E-Learning sangatlah membantu.

Dan dengan diterapkannya sistem E-Learning diharapkan dapat membuat peserta didik menjadi bahan explicit knowledge. Explicit knowledge adalah suatu pengetahuan yang telah berhasil terdokumentasikan, yang memiliki suatu sifat struktural, sistematis dan mudah untuk dikomunikasikan dan dibagikan kepada orang lain, entah bersifat pribadi

maupun publik. Pengetahuan perlu disimpan, disebarluaskan, diaplikasikan, dimanfaatkan dan digunakan untuk kesejahteraan manusia melalui organisasi atau perusahaan. Pengelolaan semua itu disebut Knowledge Management.

Seiring dengan perkembangan teknologi maka E-Learning sendiri mengalami banyak perubahan dan sekarang dapat menjangkau hampir seluruh segi dari kehidupan manusia sendiri. Sehingga banyak negera yang sudah menerapkan proses E-Learning di negara nya karena tuntutan dari kemajuan jaman yang sangat pesat. Akan tetapi, pendidikan di Negara Nusantara yang kita cintai masih belum menunjukan adanya kemauan dari setiap individu untuk memanfaatkan media internet yang ada dengan proses belajar mengajar. Bahkan Menurut survei Political and Economic Risk Consultant (PERC), kualitas pendidikan di Indonesia beradapadaurutan ke-12 dari 12 negara di Asia. Angka tersebut bisa sampai tercapai karena dari segi pengajar dan pelajar di Indonesia memiliki masing - masing masalah yang tidak kunjung menemukan jalan penyelesaian, sehingga pendidikan di

Indonesia memiliki timbunan permasalahan.

Penyebab dari rendahnya kualitas pendidikan di Indonesia, Dikarenakan kurangnya perhatian dari segi pemerintah terhadap program - program yang dicanangkannya. Kasus putus sekolah anak - anak usia sekolah di Indonesia juga masih tinggi menurut Sekretaris Direktorat Jendral Perguruan Tinggi Dr. Ir. Patdono Suwignjo, M. Eng, Sc di Jakarta,"Berdasarkan data Kemendikbud 2010, di Indonesia terdapat lebih dari 1,8 juta anak setiap tahun tidak dapat

melanjutkan pendidikan.Sebenarnya banyak hal penyebab dari masalah tersebut namun, dua faktor terbesar dari masalah tersebut, yaitu faktor ekonomi keluarga dan faktor pernikahan dinill. Dari segi pelajar pun kita dapat menemukan kesimpulan bahwa masyarakat Indonesia sendiri masih kesulitan untuk mendapatkan pengetahuan secara global

Dan bila di telaah lebih dalam sebenarnya pendidikan di Indonesia mengalami kemunduran secara drastis karena kurangnya undang - undang yang mengatur tentang kejelasan dan ketegasan apabila terdapat sejumlah pendidik yang melenceng dari tugasnya. Sebgai contoh sering kita jumpai dari beberapa guru di 
Indonesia mengajarkan sesuatu yang tidak semestinya, senior memukuli junior nya sampai meninggal dan guru tidak ada tempat saat kejadian. Masalah tersebut sebenarnya tidak bisa hanya menyalahkan kepada muridnya saja namun seharusnya ada tindakan dari pihak berwenang untuk menangani pihak - pihak sekolah karena lalai dalam menjaga tiap - tiap murid yang ada di dalam sekolah.

Penyebab lain dari rendahnya kualitas pendidikan di Indonesia adalah kualitas pendidikan dari pengajar. Kurikulum yang dipakai saat ini tidak lah sesuai dengan kemajuan teknologi yang sudah sangat pesat, dan adanya program dari pemerintah yang mengharuskan pelajaran formal 9 tahun tanpa melihat kebutuhan khusus dari pelajar yang tidak sesuai dengan kondisi masyarakat di luar Indonesia. Sehingga tidak menutup kemungkinan bahwa pelajar di Indonesia cenderung kurang kreatif dan hanya sekedar -bersekolah\| untuk mendapatkan Title yang nantinya akan dipakai saat ingin melamar kerja. Dan menjadikan lulusan di Indonesia hanya pintar mencari kerja tanpa adanya pemikiran untuk membuat lapangan kerja sendiri.

Dan adanya kurang pengertian dari pihak orang tua karena keluarga adalah tempat pertama di kehidupan kita sebagai manusia. Namun kebanyakan orang tua meremehkan tindakan dan perilaku mereka terhadap anak - anak mereka. Sebagai salah satu contoh terdapat orang tua yang memukul istri atau suami di depan anak anaknya. Perilaku mereka yang mereka perhadapkan dengan anak - anak mereka akan menjadi pendidikan pertama yang di lihat dan kemungkinan besar akan mempengaruhi sifat dari anak tersebut. Sehingga tidak menutup kemungkinan bahwa anak tersebut nanti kemudian hari akan menggunakan pendidikan awal di keluagr nya di terapkan di kehidupan baru mereka. Pendidikan macam itulah yang semakin

menyebabkan rendahnya kualitas pendidikan di Indonesia.

Teknologi telah merambah di semua sendi kehidupan secara ekstensif maupun intensif, dan banyak terjadi kasus - kasus yang sebelumnya belum pernah terjadi karena kemajuan teknologi di jaman serba teknologi seperti sekarang ini. Bahkan baru - baru ini kita sebagai warga Indonesia telah di hebohkan dengan adanya sekumpulan mahasiswa yang berhasil membobol sistem keamanan di luar negeri maupun di dalam negeri, karena bantuan dari teknologi. Padahal sekumpulan mahasiswa tersebut tidaklah menonjol di kalangan teman sebayanya, bahkan tidak ada yang mengetahui mereka adalah seorang peretas sistem yang handal. Yang artinya dapat disimpulkan bahwa dengan majunya teknologi, dapat mengubah karakter, perilaku, dan kemampuan seseorang. Entah dapat berakibat positif maupun negatif

Dan dengan adanya dampak dampak yang bisa dikatakan negatif dan mempengaruhi kehidupan seseorang khususnya masyarakat Indonesia, perlunya ada campur tangan dari pemerintah khususnya yang memiliki kemampuan lebih di bidang TI untuk

memantau penggunaan kemajuan teknologi di Indonesia dan dapat dengan segera menindaklanjuti tindakan kriminal yang berbau $\mathrm{TI}$. 
Dengan bantuan teknologi, proses pendidikan di Indonesia tentunya akan membuat negara Indonesia bisa bersaing dengan negara asing, oleh karena itu perlu adanya proses kajian ulang dari segi filosofis negara Indonesia sendiri. Dikarenakan untuk mengurangi efek negatif dari kemajuan teknologi, maka dapat dilakukan dengan merumuskan kerangka dasar nilai bagi pengembangan ilmu. Kerangka dasar ini tentunya harus yang sudah mengakar kuat dengan pribadi bangsa Indonesia sendiri dan sudah bisa dikatakan sebagai sifat dasar dari rakyat Indonesia, yaitu Pancasila.

Sikap Indonesia yang kebanyakan masyarakatnya masih bersifat apatis, dan membuat kemajuan pendidikan di negara kita terus mengalami kemunduran. Dan cenderung menggunakan kemajuan teknologi hanya untuk hal - hal yang menyenangkan tanpa adanya keinginan untuk menggunakan teknologi sebagai sumber kemajuan bangsa. Oleh karena itu perlu adanya suatu tindakan, untuk membuat segi pandang baru dari Indonesia dan membuat rakyat Indonesia sadar akan pentingnya teknologi sebagai jalan untuk membuat Indonesia jauh lebih berkembang dari sebelumnya

Tujuan dari analisa ini yaitu menjadikan Masyarakat Indonesia terutama anak bangsa menjadi seseorang yang berwawasan global serta mempunyai karakter CKKIT(cerdas, kritis, kreatif, inovatif, dantanggungjawab dalam pendidikan kewarganegaraan, pada Elearning knowledge management.

\section{RUMUSAN MASALAH}

Dalam penelitian ilmiah ini akan membahas masalah, yaitu :

1. Pembelajaran yang didasari dengan wawasan global.

2. E-learning sebagai knowledge management.

3. Nilai - nilai Pancasila.

4. Analisa penggunaan media social dalam masyarakat.

\section{METODOLOGI}

Metode yang digunakan adalah meteode analitis. Penetlitian ini menggunakan pendektan kualitatif karena mekeankan kehidupan realitas sosial yang sesuai apa adanya. Peneliti dengan apa yang diteliti memiliki relasi yang sangat dekat. Penulis mengumpulkan data - data yang menggambarkan peristiwa-peristiwa yang dialami dan permsalah yang dialami setiap individu.

Peneliti membuat seluruh gambaran yang lengkap yang dibentuk melalui sususnan kata dan kalimat yang, menulis dan mengkaji pandangan para informan secara rinci, dan melakukan penelitian secara alamiah. Penelitian ini juga menganilisi secara deskriptif antara pengajar dan peserta didik agar

memanfaatkan pendidikan sebagai Pembelajaran Berwawasan global, Berkarakter, dan E-Learning dalam berbasis knowledge management untuk membantu memajukan pendidikan di sekolah - sekolah. Lalu dengan adanya faktor rasa tidak pernah puas, maka banyak ditemukan nya penemuan - penemuan baru seperti halnya dengan munculnya ilmu - ilmu baru di bangku 
sekolah dan adanya fakultas - fakultas baru di perkuliahan.

Penelitian kualitatif sering disebut sebagai penelitian naturalistik, karena penelitian kualitatif memiliki sifat penelitian yang bersifat natural alami atau wajar saja, sebagaimana adanya tanpa adanya klise ataupun tambahan apapun atau bisa disimpulkan dengan penelitian kualitatif adalah penelitian yang berdasarkan realita(-Terkutip dari : Nasution. S\|). Oleh karena itu, peristiwa yang diperoleh juga adalah situasi atau peristiwa nyata yang berisikan tentang membangun ilmu pengetahuan berwawasan global yang berlandaskan pada nilai - nilai Pancasila sebagai karakter asli bangsa Indonesia.

Hasil dari penelitian menunjukan bahwa Pancasila dapat dijadikan sebagai filter atas nilai - nilai global yang tidak sesuai dengan pribadi bangsa Indonesia. Membangun pendidikan berwawasan global berdasarkan nilai - nilai Pancasila sebgai karkater Indonesia, sebenarnya dapat kita lihat dari pancasila sila ke-2 yakni -kemanusiaan yang adildanberadab\|l. Karena di dalam sila kedua memiliki arti, tidak ada bedanya antara orang pertama dan yang lainnya.

Dengan kata lain sila ke-2 menggambarkan bahwa tidak ada perbedaan antara manusia entah seseorang tersebut berkulit hitam ataupun berkulit putih, beragama ataupun tidak beragama, pendek ataupun tinggi, kaya ataupun miskin, semua terlihat sama dengan nilai pancasila ke-2. Sehingga hal tersebut akan menjadikan sila kedua sebagai pintu masuk bagi pergaulan internasional. Manusia tidak diihat dari mana ia dilahirkan ataupun bagaimana latar belakang dan masa lalunya, namun dapat dilihat dari harkatdan martabat. Para pendahulu sudah mengetahui sejak awal bahwa Indonesia harus memiliki dasar negara yaitu Pancasila, karena mereka menyadari akan jaman yang terus berubah dan menjadi lebih baik. Apabila kita tidak mengikuti arus jaman yang ada maka kita akan lebih cepat tertinggal.Olehkarenaitu, perludikembangkan ide yang bisamembukapintupergaulaninternasional.

Ciri khas yang terkandung di dalam ilmu pengetahuan adalah rasional, antroposentris, dan cenderung sekuler, dengan suatu etos kebebasan. Meskipun ilmu pengetahuan tetap masih memiliki berbagai dampak dan tidak selalu positif namun ada dampak negatif pula. Dampak positif dalam arti ilmu pengetahuan yaitu, dengan adanya kemajuan ilmu pengetahuan teknologi tentunya akan membuat suatu terobosan baru yaitu akan adanya teknologi baru yang akan mempermudah seseorang dalam menjalankan aktivitasnya. Dampak negatif dalam bidang ilmu pengetahuan, akan

mendorongnya perkembangan sifat arogansi ilmiah dengan menjauhi ilmu ilmu agama, etika yang akhirnya dapat menghancurkan kehidupan manusia sendiri.

Akhirnya tidak dapat terelakkan bahwa ilmu pengetahauan dan teknologi saling terkait satu sama lain. Dan sampai saat ini pendidikan ilmu pengetahuan dan kemajuan teknologi juga telah menjangkau seluruh segi kehidupan manusia. 


\section{PEMBAHASAN}

\section{Definisi Pembelajaran}

Pembelajaran adalah proses komunikasi antaradua orang atau lebih yang salah satunya harus ada yang memiliki peran sebagai pengajar yaitu - gurull dan yang lain memiliki peran sebagai belajar yaitu peserta didik. Dan diantara kedua peran tersebut biasanya terdapat interaksi timbale balik antara satu sama lain, tetapi tidak menutup kemungkinan untuk tidak adanya interaksi timbal balik.

Tujuan dari pembelajaran menurut Oemar Hamalik (2005) adalah suatu deskripsi mengenai tingkah laku dan perilaku yang diharapkan tercapai oleh siswa setelah berlangsung pembelajaran.

$\begin{array}{llr}\text { Robert F. Mager (1962) juga } & \begin{array}{r}\text { jugan } \\ \text { mengemukakan }\end{array}\end{array}$
pembelajaran adalah perilaku yang hendak dicapai atau yang dapat dikerjakan oleh pesrta didik pada kondisi dan tingkat kompetensi tertentu. Namun definisi pembelajaran sendiri menurut penulis yaitu, adalah suatu tingkah laku dari seseorang yang memiliki tujuan awal untuk mencapai suatu tingkatan kompetensi yang lebih dari sebelumnya setelah mengikuti pelajaran kinetic ataupun non-kinetik. Yang nantinya akan di ukur dengan suatu tolak ukur untuk

menjadi patokan apakah proses pembelajaran itu sendiri berhasil atau tidak.

Tercapainya tujuan awal dari pembelajaran adalah tolak ukur dari berhasil tidaknya proses pembelajaran. Oleh karena itu tujuan pembelajaran sebelumnya haruslah jelas dan tegas, sehingga hasil akhir dari proses pembelajaran tidak melenceng jauh dari tujuan awal. Kualitas dari pendidik dan materi pembelajaran juga menjadi tolak ukur yang tidak kalah penting dari tujuan awal pembelajaran, karena apabila pendidik tidak memahami materi pendidikan yang akan di ajarkan tentunya akan membuat tujuan awal dari pembelajaran akan sedikit pudar, begitu juga sebaliknya.

Jika dapat disimpulkan pembelajaran dapat di kelompokan menjadi beberapa komponen, dan komponen tersebut saling berkaitan satu sama lain yaitu: 1.) pendidik, 2.) peserta didik, 3.) materi pembelajaran, 4.) metode pembelajaran, 5.) media pembelajaran, 6.) evaluasi pembelajaran. Proses belajar mengajar akan lebih efisien dan efektif jika ada nya pendidik dan peserta didik, serta memiliki materi pembelajaran dan di dampingi dengan metode pembelajran dan media pembelajaran dan di akhiri dengan evaluasi pembelajaran yang saling menunjang satu sama lain

Pendidik haruslah memiliki sifat yang percaya akan kemampuan peserta didik dan membantu para peserta didik nya, namun pendidik juga harus paham dan mengerti saat dimana Ia harus menguji para peserta didiknya agar akan ada nya perkembangan kemampuan dari sebelumnya. Dan peserta didik juga haruslah memiliki sifat percaya kepada pendidik, namun perlu ada nya rasa kreativitas sendiri dari para peserta didik agar tidak merasa selalu puas dengan apa yang diajarkan pendidik. Lalu juga perlu adanya materi pembelajaran yang harus diajarkan dengan metode pembelajaran yang seunik mungkin, agar para peserta 
didik tidak mengalami kemunduran dalam hal kreativitas. Namun juga perlu diperhatikan agar materi dan metode pembelajaran tidak melebihi batas kemampuan peserta didik dan tidak memberi beban antara satu sama lain. Dengan adanya media pembelajaran juga akan membantu proses pembelajaran dengan sempurna, dikarenakan semakin bagusnya media pembelajaran akan memberikan kenyamanan kepada peserta didik dan pendidik. Lalu akan di akhiri dengan evaluasi pembelajaran yang nantinya akan menjadi tolak ukur akan keberhasilan dalam proses belajar

\section{Model Pembelajaran Terhadap Lingkungan Sekitar}

Pertumbuhan dan perkembangan siswa tidak hanyalah berada di balik tembok yang dinamakan kelas, namun pertumbuhan dan perkembangan siswa dapat terjadi di luar keals.proses pembelajaran yang selalu di kelas akan membua mental dan pikiran para siswa tertutup, sama seperti ibarat - kura - kura di dalam tempurung\|, mereka tidak akan dapat mengetahui kehidupan di luar kelas, tidak akan tahu menahu kehidupan bermasyarakat. Mereka hanya akan mnerima pembelajaran secara formal, dan jika keadaan seperti ini terus menerus berlarut, tentunya akan ada perbedaan mental dengan siswa yang di biasakan untuk mengalami kehidupan di luar kelas. Mereka akan merasa terkekang oleh tugas - tugas yang diberikan, merasa kebebasan mereka di batasi, dan mau tidak mau mereka harus menerima secara mentah mentah semua pelajran yang di ajarkan di sekolah. Kebanyakan siswa akan kehilangan atau tidak berkesempatan untuk mengembangkan bakat yang disukainya

Setiap peserta didik pastinya memiliki bakat tertentu di bidangnya masing - masing, dan tentunya bakat setiap siwa tidak lah mungkin bisa sama. Namun apabila mengikuti proses pembelajran di sekolah saja, maka bakat terpendam mereka tidak akan dapat berkembang. Bakat tersebut akan terus berkembang apabila selalu di asah, bahkan ada sebagian orang yang bakatnya harus terpendam karena ia tidak memilki kesempatan untuk melatih ataupun

menunjukannnya. Dalam hal ini pendidikan lah yang memegang peran utama dari bakast seseorang semasa hidupnya.

Dengan melakukan pembelajran di lingkungan akan bisa meminimalisir tingkat kejenuhan seseorang, dan gairah mereka akan belajar pastinya meningkat. Dengan tingak kegairahan akan belajran yang meningkat tentutnya akan membuat proses pembelajran lebih cepat di cerna, dan membuat bakat yang dimiliki akan semakin muncul.

Dengan tujuan pembelajaran lapangan ini adalah membuat para siswa memahami dan mempunyai pengalaman bermasyarakat sejak dini. Manfaat dari proses pembelajaran di lapangan ini akan terasa saat mereka mulai beranjak dewasa dan mengaplikasikannya di kehidupan realita. Inilah salah satu niat positif dari proses pembelajran lapangan.

Bekerja dengan belajran berbasis lingkungan, akan membuat nilai tambah bagi kehiudpan siswanya. Pasalnya dapat kita contohkan dengan pelajaran ilmu pengetahuan sosial (IPS), maka 
lingkungan sosial dan ekonomi akan menjadi laboratorium alam. Pemeblejaran ini dapat dilkaukan dengan sembari melakukan pemebrdayaan terhadap sosisal ekonomi di masyarakat, sememntara untuk siswa dpaat melakukan proses pembelajran dengan lebih baik dan efisisien layaknya di kehidupan realita.

Pembelajaran dengan berbasis lingkungan akan leboh bermanfaat jika diberlakukan kepada siswa dasar $(7-11)$ tahun. Karena di saat umur tersebut, para siswa biasanya akan lebih senang belajar lewat metode eksplorasi dan mengenal alam. Hal tersebut dapat dilakukan untuk memecahkan masalah sifat anak yang tidak mencintai alam.

\section{Model E-learning}

Sistem pembelajaran dengan metode E-Learning masih sangatlah baru di negara kita. Elektronic Learning yang sekarang sering kita dengar dengan ELearning. Kata ini berasal dari -ell yang berarti electronica dan -learning\| yang artinya pembelajaran. E learning berarti pembelajaran dengan menggunakan bantuan sistem elektronika. Sedangkan menurut Learn Frame bahwa e-learning, disebut juga Tb-Learning (Technologybased Learning),Tb-Learning adalah sistem pendidikan yang menggunakan

semua aplikasi elektronik untuk mendukung belajar mengajar termasuk jaringan Komputer

Sebenarnya sistem E-Learning sudah lama di dengar oleh kita, namun kebanyakan masih salah mengartikan apa itu E-Learning. Biasanya pemkiran mereka, bahwa dengan E-Learning kita tidak akan pernah bisa lepas dari komputer, belajar di depan komputer dan tersambung dengan internet. Namun pengertian ini sebenarnya sangatlah tidak benar, karena dampak kemajuan dari industrialisasi yang sudah sangat maju. Memungkinkan kita untuk tidak perlu lagi harus duduk - duduk di depan komputer saja, namun kita bisa sambil dengan tiduran ataupun dengan mendengarkan musik. Dan E-Leearnign erat dengan berbagai istilah - istilah komputer seperti m-learning, web-based learning, hybrid / blended learning.

Setelah kemunculan E-Learning, munculah program - program lain yang tidak jauh berbeda dengan E-Learning, hanya saja program - program baru ini jauh lebih efektif ketimbang E-Learning. Karena E-Learning pada awalnya hanya merujuk pada sistem Elektronik, namun karena seirinf kreatifitas manusia

munculah M-Learning. M-learning sebenarnya sama dengan E-Learning, hanya saja pembeda nya adalah sistem dan perangkat komputer yang dibawa sangat lah jauh lebih efisien yaitu -Mobile Learning $\|$.

\section{Definisi Knowledge Management}

Knowledge Management adalah suatu rangkaian kegiatan yang digunakan oleh organisasi atau perusahaan untuk mengidentifikasi, menciptakan, menjelaskan, dan mendistribusikan pengetahuan untuk digunakan kembali, diketahui, dan dipelajari di dalam organisasi. Maka di dalam knowledge management atau disebut dengan

manajemen pengetahuan, biasanya terdapat berbgai pihak dengan peran masing - masing. Di dalamnya terdapat peran penemu, produsen, pengembang, , dan pengguna. 
Penemu adalah pihak pertama yang berpikir bagaimana kerja komputer dengan fungsi untuk membantu mempermudah segala sesuatu di berbagai bidang. Produsen adalah orang yang mempunyai peran berpikir tentang bisnis komputer menjadi lebih menarik, pembiayaan untuk proses selanjutnya, dipasarkan, dan sebagainya. Pengembang adalah orang yang berpikir untuk mengoptimalkan cara kinerja komputer menjadi lebih canggih dengan bantuan teknlogi, internet, appliacation software, dan lain - lain. Dan pengguna adalah pasar atau pembeli yang tertarik, mampu ,

dan berkeinginan untuk dapat menggunakan perangkat teknlogi digital ini.

\section{Berdasarkan}

pengamatan, pengguna sebagai SDM sering kali menjdai kendala bagi efektivitas dari pemakaian aplikasi digital ini dalam dunia pendidikan. Kelompok pendidik dan peserta didik lah yang akan menjadi sasaran terhambat nya dari hal tersebut. Hambatan tersebut dapat berupa daya beli masyarakat. Sebgai contoh adalah fungsi warnet dengan lokasi yang berada di tengah kota harus berada dalam jangkauan satelit, sangat penting karena jika tidak terjangkau internet akan susah terpakai dan menghambat jalannya knowldege managament. Warnet menjadi pilihan termurah untuk mengakses internet dengan cepat dan efisien. Produk komputer dalam negeri juga cenderung lebih murah daripada komputer dengan ber merk.

Mempersiapkan SDM yang berkualitas dan kompetitif adalah hasil utama dari pendidikan. Karena hanya dengan pengetahuanlah semua perubahan dapat disikapi dengan tepat. Ketatnya bidang usaha dalam era globalisasi

membuat para pendiri organisasi memikirkan kembali SDM yang dimiliki dan dengan memilih SDM yang berkualitas tentunya akan membuat organisasi tersebut lebih hebat dari sebelumnya.

\section{Konsep Pendidikan Karakter}

-Karakter adalah watak, tabiat, akhlak, atau kepribadian individu yang terbentuk dari hasil internalisasi dan eksternalisasi dari berbagai kebajikan (virtues) yang diyakini dan digunakan sebagai landasan untuk cara pandang, berpikir, bersikap, dan bertindak untuk apa yang terjadi selanjutnyall menurut pihak Kementerian Pendidikan Nasional (2010) demikianlah definisi karakter. Sebagai perbandingan definisi karakter dari berbagai ahli yaitu menurut Berkowitz (1997) yaitu —-sehimpunan karakteristik psikologis seseorang yang

mempengaruhi kemampuan dan kecenderungan orang itu untuk berfungsi secara morall. Dan dapat di definisikan dari kedua ahli tersebut bahwa karakter adalah sesuatu yang diyakini atau dipercayai oleh manusia itu sendiri dalam melakukan suatu tindakan sehingga apa yang di lakukan nya benar atau salah, adalah ia sendiri dan keputusan tersebut menurut sudut pandang dari apa yang sudah ia alami selama hidupnya. Secara lebih dasar definisi karakter adalah bentuk dasar dari manusia itu sendiri.

Menurut Lickona, (1991) Hal utama di sini adalah bahwa karakter merupakan konsep psikologis kompleks. Karakter menyimpulkan kapasitas otak 
manusia untuk berpikir tentang benar dan salah, mengalami emosi secara moral, ikut serta dalam perilaku berbau moral, meyakinikebaikan-kebaikan moral. Dan selalu ingin bertindak dengan kejujuran,

ketulusan, tanggungjawab, dankarakteristik-karakteristiklainnya yang mendukungkefungsian moral

Karakter dapat diartikan ke dalam bentuk turunan, hati, sifat, tabiat, temperamen, dan watak. Karakter dalam artian ini dapat diaplikasikan ke dalam bentuk tingkah laku atau tindakan. Orang yang tidak mengaplikasikannya dengan nilai kebaikan, contohnya tidak jujur, kejam, pelit, dan berbagai perilaku lainnya akan dikatakan sebagai orang yang berkarakter jelek. Namun apabila seseorang mengaplikasikan nilai - nilai kebaikan di dalam segala tindakannya dan tingkah laku nya maka akan dikatakan sebagai orang yang berkarakter mulia.

\section{Karakter Peserta Didik yang Diharapkan}

Karakter peserta didik yang dimaksudkan dalam penulisan ini adalah karakter yang bersifat mulia yang

nantinya diharapkan akan dapat berkembang. Dalam hal ini mengacu kepada pengertian bahwa peserta didik akan di arahkan agar memiliki kepribadian, watak, sifat, tabiat, dan tingkah laku yang baik atau mulia. Karakter yang seperti demikian akan mengarah kepada sikap, perilaku, motivasi, dan kecakapan yang memenuhi standar nilai dan norma yang dijunjunt tinggi dan dihargai.

Dan bagaiamanapun juga terlepas dari itu semua, negara kita telah mengalami krisis mentalitas, moral dan karakter peserta didik sejak dini yang pastinya akan merusak moral dan karakter pribadi negara kita. Dan masalah seperti ini tidak bisa hanya kita pikir adalah kesalahan dari pihak sekolah, namun ini adalah masalah atau kesalahan dari sistem lingkungan yang ada di sekitar para siswa. Maka dari itu kita tidak hanya bisa memperbaiki masalah tersebut hanya dari sekolah, maka perlunya ada perombakan sikap dari dalam dan dari luar sekolah. Dan dari masalah tersebut dapat di asumsikan bahwa masih banyak orang - orang di luar sekolah yang merusak generasi bangsa. Dengan kata lain masalah ini haruslah diselesaikan dengan cara kerjasama dengan seluruh peran masing - masing masyarakat di Indonesia, entah dari dalam rumah tangga maupun di luar rumah.

Peserta didik dikatakan telah berhasil mencapai karakter yang bersifat mulia jika ia sudah memenuhi kriteria karakter mulia. Seperti tindakaknnya selalu di penuhi dengan sifat reflektif, percaya diri, rasional, logis, kritis, analitis, kreatif dan inovatif, mandiri, bertanggung jawab, dapat dipercayai, jujur, tidak bersungut sungut, pemaaf, rendah hati, sopan, baik, berhati lembut, peduli dengan sesama, tidak melupakan akan orang tua, mempunyai pendirian yang teguh, tidak ikut - ikut dalam hal negatif, tidak suka provokatif, tidak suka menuduh, tekun, gigih, rajin, ulet, berdisiplin diri,

menghargai waktu, adil, dapat mengendalikan emosi diri dalam berbagai situasi, cinta akan keindahan, tabah, terbuka , tertib, antisipatif, bersahaja, bersemangat, pantang menyerah, dinamis, hemat/efisien. 
Disamping itu semua siswa tersebut juga harus memiliki kesadaran untuk berbuat yang terbaik atau unggul dan mampu beritndak sesuai dengan situasi dan yang poternsi yang dimiliki.

Mereka dapat mengaplikasikan perkembangan sifat atau perilaku positif yang ia miliki sebagai individu yang berada di tengah - tengah masyarakat. Peserta didik yang memiliki sifat atau perilaku unggul atau positif pasti akan selalu mengutamakan nilai kebaikan kepada Tuhan Yang Maha Esa, dirinya, sesama nya, lingkungannya, bangsa, dan negara serta negara internasional dengan mengedapankan potensi atau bakat yang sudah ia miliki dan selalu disertai dengan kesadaran secara emosi dan motivasi yang dimilikimya akan selalu terpancar dalam apa yang dilakukannya.

Pada hakikatnya pendidikan memiliki tujuan awal menanamkan sifat dan perilaku yang luhur dan mulia dalam mengembangkan perilaku ataupun pemikiran yang positif kepada warga sekolah dan masyarakat yang meliputi komponen pengetahuan, kesadaran, atau kemauan, dan tindakan untuk melaksanakan nilai-nilai tersebut. Dalam pelaksanaan pendidikan di sekolah, semua komponen sekolah harus lah dilibatkan dalam usaha mengembangkan karakter seorang siswa maupun mahasiswa. Termasuk komponen dari pendidikan sendiri yaitu, materi pembelajran haruslah jelas, kurikulum pembelajaran juga harus disamakan dengan setiap provinsi maupun di pelosok - pelosok, proses pembelajaran dan penilaian, penanganan atau pengelolaan mata pelajaran, perencanaan dan pengelolaan pelaksanaan aktivitas ataupun kegiatan ekstrakurikuler, pemebrdayaan sarana dan prasarana pendidikan di tiap sekolah, dan etos kerja yang dimiliki karyawan - karyawan sekolah maupun orang - orang di sekitar sekolah (lingkungan).

Sebagai pembentuk karakter siswa maka diperlukan guru yang memiliki kepribadian yang sesuai dengan nilai nilai luhur yang di anggap mulia. Karena guru adalah seseorang yang nantinya akan menjadi teladan bagi seorang siswa. Apabila guru tidak dapat dikatakan memiliki nilai karakter budi dan luhur, tentunya seorang siswa tidak akan dapat menjadi lebih baik dari gurunya. Maka seorang guru juga harus memiliki nilai nilai pendidikan yang berbudi luhur dan sesuai dengan nilai - nilai norma sesuai dengan nilai pancasila.

Saat ini pendidikan karakter telah menjadi berita utama dan salah satu penyebab dari berbagai sumber masalah yang ada di negara kita. Selain menjadi bagian dari proses pembentukan aklhak dari generasi penerus bangsa, pendidikan juga menjadi dasar dari masalah tentang berbagai masalah di Indonesia. Karena salah satu penyebab masalah di Indonesia juga bersumber dari rendahnya tingkat kecerdasan bangsa Indonesia yang sebenarnya kurang bisa merata.

\section{Berwawasan Global}

Jika di artikan wawasan memiliki arti yaitu sebagai pengetahuan ataupun informasi. Sedangkan global adalah mendunia, maka wawasan global adalah pengetahuan ataupun informasi yang mendunia

Implikasi dari pendidikan berwawasan global tidak hanya bersifat 
sebagai perombakan kurikulum, melainkan juga perombakan sistem,

struktur, dan proses pendidikan.

Pendidikan dengan kebijakan dasar sebagai kebijakan sosial tidak lah cocok dengan pendidikan berwawasan global.

Pendidikan berwawasan global harus didasarkan dari dua kebijakan yaitu kebijkan sosial dan kebijakan mekanisme pasar.

Kebijakan mekanisme pasar yaitu 1.) fleksibel-Adaptif, yaitu harga barang jualan haruslah sefleksibel mungkin dengan barang yang juga sesuai dengan jamannya, karena bila tidak maka barang jualan tersebut makin lama akan semakin tenggelam; 2.) kreatif-demokratis, yang berarti barang jualan harus berbeda dengan yang lain dan bersifat demokratis yaitu antara penjual dengan pembeli memiliki pendapat masing - masing namun tidak adanya unsur paksaan. Jika di kaitkan dengan proses pendidikan, maka tentunya unsur - unsur tersebut akan menunjang pendidikan. Maksud fleksibel-adaptif, pendidikan haruslah fleksibel yang artinya bisa berubah - ubah dan adaptif yang artinya dapat mengikuti jamannya. Maksud dari kreatif - demokratis, pendidikan harus lah berbeda dari yang lain dengan adanya unsur

demokratis yaitu adanya saling pengemukakan pendapat secara bebas dan tidak adanya unsur paksaan di dalamnya. Ke-empat unsur tersebut akan sangat menunjang tinggi kemampuan pendidikan, sehingga sangat cocok untuk dijadikan kebijakan dasar dari pendidikan berwawasan global.

Setiap negara haruslah memiliki visi pendidikan nasional yang kuat, karena visi inilah yang nantinya akan menjadikan pedoman dari pendidikan di negara

tersebut. Visi pendidikan negara Indonesiaadalah — terwujudnya individu manusia Indonesia baru yang memiliki sikap dan wawasan keimanan dan akhlak tinggi dan mulia, kemerdekaan dan demokrasi, toleransi dan menjunjung tinggi HAM, saling pengertian dan berwawasan globall.

Pendidikan sangat berkaitan erat dengan globalisasi, karena pendidikan akan dinilai terlambat atau tertinggal apabila pendidikan tersebut tidak dapat mengikuti kemajuan teknologi yang terus berkembang. Oleh karena itu pendidikan haruslah bisa berupaya untuk mengembangkan kemampuan seseorang agar dapat mengikuti jaman yang terus menerus mengalami perubahan dengan memiliki sifat yang kreatif, penuh kebebasan, dan tanggung jawab. Di samping itu pendidikan juga harus menciptakan lululsan yang mampu memahami masyarakatnya dengan dapat mencipatakan terobosan baru dalam masalah - masalah yang ada di dalam kehidupan bermasyarakat. Salah satu cara yang dapat dilakukan adalah dengan

mengembangkan pendidikan yang berwawasan global.

Pendidikan berwawasan global dapat dikaji berdasarkan dua perspektif: Kurikuler dan perspektif Reformasi. Dari perspektif kurikuler berarti menyajikan kurikulum yang bersifat interdisipliner, multidisipliner dan transdisipliner. Berdasarkan perspektif reformasi pendidikan tidak hanya sebagai kebijakan sosial, melainkan suatu kebijakan yang 
berada di tengah - tengah kebijakan sosial dan kebijakan mekanisme pasar.

Tujuan tentang pendidikan nasional di bidang makro adalah — membentuk suatu organisasi pendidikan yang di dalamnya akan membentuk suatu inovasi baru dalam dunia pendidikan dengan memiliki kemampuan komunikasi sosial yang positif dan memiliki SDM yang tangguhll. Sedangkan tujuan tentang pendidikan nasional di bidang mikro adalah -membangun insan yang memiliki pribadi yang taat dengan Tuhan, cerdas,

kritis, kreatif, inovatif dan tanggungjawab\|.

Terwujudnya peserta didik berilmu pengetahuan berwawasan global

Pendidikan global adalah upaya dari manusia untuk menanamkan pandangan mengenai dunia berdasarkan dari ilmu pendidikan yang bertujuan untuk tidak hanya berwawasan secara formal namun untuk bisa berwawasan di kehidupan bermasyarakat. Dengan adanya pendidikan global peserta didik diharapkan dapat mampu berpikir secara kritis tentang fokus kajian segala hal yang mendunia dengan bercirikan perubahan, independensi, dan pluralisme.

Peserta akan dikembangkan segala

tentang pengetahuan, sikap, dan keterampilannya agar disesuaikan dengan kehidupan jaman sekarang sehingga peserta diharapkan dapat melewati sepak terjang dari kerasnya dunia. Pendidikan global sendiri sangat penting karena di dalam pendidikan global terdapat hampir semua aspek tentang kehidupan real seperti sumber daya manusia, bahasa, seni budaya, ekonomi, teknologi informasi dan komunikasi, ekologi, dan sebagainya yang telah terdapat di dalam pendidikan global.

Oleh karena itu berdasarkan pentingnya pendidikan global, diharuskan lah kita dapat bersaing secara sehat di era globalisasi dan tidak tertinggal dengan kemajuan yang ada. Adapun tujuan pendidikan global yang seharus nya kita perhatikan :

1. Menumbuhkan kesadaran bahwa kita sekarang maupun nanti akan tetap menjadi bagian dari suatu masyarakat

2. Membiasakan kehidupan bermasyrakat yang penuh dengan tanggung jawab dan bijaksana

3. Menyadarkan Anda akan pentingnya Anda sebagai perilaku aktif di dalam kalangan masyarakat

Pendidikan global mempunyai pandangan yaitu bahwa dunia itu adalah satu. Pendidikan global mencoba untuk membuka sekat-sekat antar budaya secara global, dan menjadikannya lebih inklusif.. hal tersebut membuktikan bahwa sebenarnya Pendidikan Global memiliki tujuan mulia yaitu untuk mempersatukan segala yang berbeda. Ruang lingkup yang dimiliki oleh pendidikan global adalah :

1. Adanya kesadaran terhadap pandangan secara global

2. Memiliki pemahaman dengan sistem - sistem global

3. Mengerti betul sejarah globalisasi

4. Adanya rasa toleransi terhadapa budaya lain

Dengan melihat ruang lingkup tersebut, dapat dilihat bahwa pendidikan global memiliki beberapa karaketeristik yang baik 
1. Memiliki saling keterkaitan dengan yang lain atau sering disebut - relasill

2. Materi pengajaran yang ada sesuai dengan fakta tanpa adanya klise atau berita Hoax

3. Membiasakan manusia untuk menerima saling perbedaan antara satu sama lain

4. Memberikan tantangan secara global yang artinya memiliki daya saing secara global, namun sehat dalam hal bersaing

5. Terbiasanya seseorang akan sifat mengikuti jaman atau sering disebut sebagai pribadi yang fleksibel

Demikian pengertian tentang pendidikan Global, dan dapat dipastikan dengan adanya pendidikan global yang dapat di atur tentunya akan membuat kemajuan bagi sistem pendidikan di Indonesia

\section{KESIMPULAN}

Dari kajian penjelasan yang telah ditulis kan dapat disimpulkan bahwa masih banyak nilai - nilai dasar dari pendidikan yang masih salah dan tidak sesuai dengan nilai- nilai pancasila, dan perlunya ada perkembangan dari karakter pendidik dan para peserta didik yang

harus sesuai dengan kehidupan bermasyarakat tanpa meninggalkan jati diri mereka sebagai bangsa Indonesia yang berbudi luhur, juga perlu adanya pembelajaran di sekolah yang di kembangkan dengan menggunakan sistem E-Learning knowledge management guna membentuk kepribadian yang mulia sejak lahir.

Adanya nilai - nilai dasar yang prlu dikembangkan dengan membangun wawasan global dalam konteks Indonesia antara lain ketuhanan, kemanusiaan, persatuan, kerakyatan, keadilan sosial, kompetisi, menghormati orang lain, kemerdekaan dan perdamaian.

Memupuk rasa nasionalisme agar dapat mengikuti dan berperan secara aktif dalam persaingan global tanpa melupakan jati diri sebagai bangsa Indonesia yang memiliki dasar nilai - nilai pancasila dalam era globalisasi yang semakin banyaknya teknologi - teknologi baru.

\section{DAFTAR PUSTAKA}

Nasution, S. 1988. Metode Penelitian Naturalistik-Kualitatif. Bandung: Tarsito

Tentang pendidikan global dikutip dari (一websitependidikan.com pengertian-pendidikan-global-danruang-lingkupnyall)

Tentang kilas balik dunia pendidikan di Indonesia - dikutip dari (—prestasiiief.org -kilas-balik-duniapendidikan-di-indonesiall)

Dikutip dari Kemendiknas. (2010). Desain induk pendidikan karakter kementrian pendidikan nasional. Jakarta: Kemendiknas.

Terkutip dari spengetahuan.com pengertian-pendidikan-menurutpara-ahli.

Kamus Besar Bahasa Indonesia (KBBI). Definisi dari pendidikan.

Sudrajat, Akhmad. 2010. -Tentang Pendidikan Karakter $\|($ dalam http://akhmadsudrajat.wordpress.co $\mathrm{m} / 2010 / 08 / 20 /$ pendidikan-karakterdi smp ) diakses 18 Oktober 2010 Berkowitz, M.W. (1997). 
INTEGRALISTIK

No.2/Th. XXIX/2018

The compl ete moral person: Upaya Mempertahankan dan Anatomy and formationl dalam J.M. Mengembangkan Jati Diri/Identitas Dubois, ed., MoralIssues in psychology: Bangsa,Jakarta: BPPN.

Personalist contributions to selected

Kohlberg, L. (1984). The

problems, 11-42. Lanham, Md.: psycology of moral development, essays

University Press of America.

on moral development, Vol. 2. New York:

Badan Pertimbangan Pendidikan Harper and Row.

Nasional, 1995, Pendidikan Budi Pekerti: 
